\title{
Correction to: In Search of the Trinity: A Dilemma for Parfit's Conciliatory Project
}

\section{Marius Baumann ${ }^{1}$}

Published online: 21 September 2021

(c) Springer Nature B.V. 2021

\section{Correction to: Ethical Theory and Moral Practice https://doi.org/10.1007/s10677-021-10161-z}

The version of the article that has originally been published online was not the one approved by the author and contained several errors.

The original article has been corrected.

Publisher's Note Springer Nature remains neutral with regard to jurisdictional claims in published maps and institutional affiliations.

The original article can be found online at https://doi.org/10.1007/s10677-021-10161-z

Marius Baumann

marius.baumann@1rz.uni-muenchen.de

1 Fakultät für Philosophie, Wissenschaftstheorie und Religionswissenschaft, Lehrstuhl V für Praktische Philosophie und Ethik, Ludwig-Maximilians-Universität München, 80539 München, Germany 